\title{
Hygrothermal Material Properties for Soils in Building Science
}

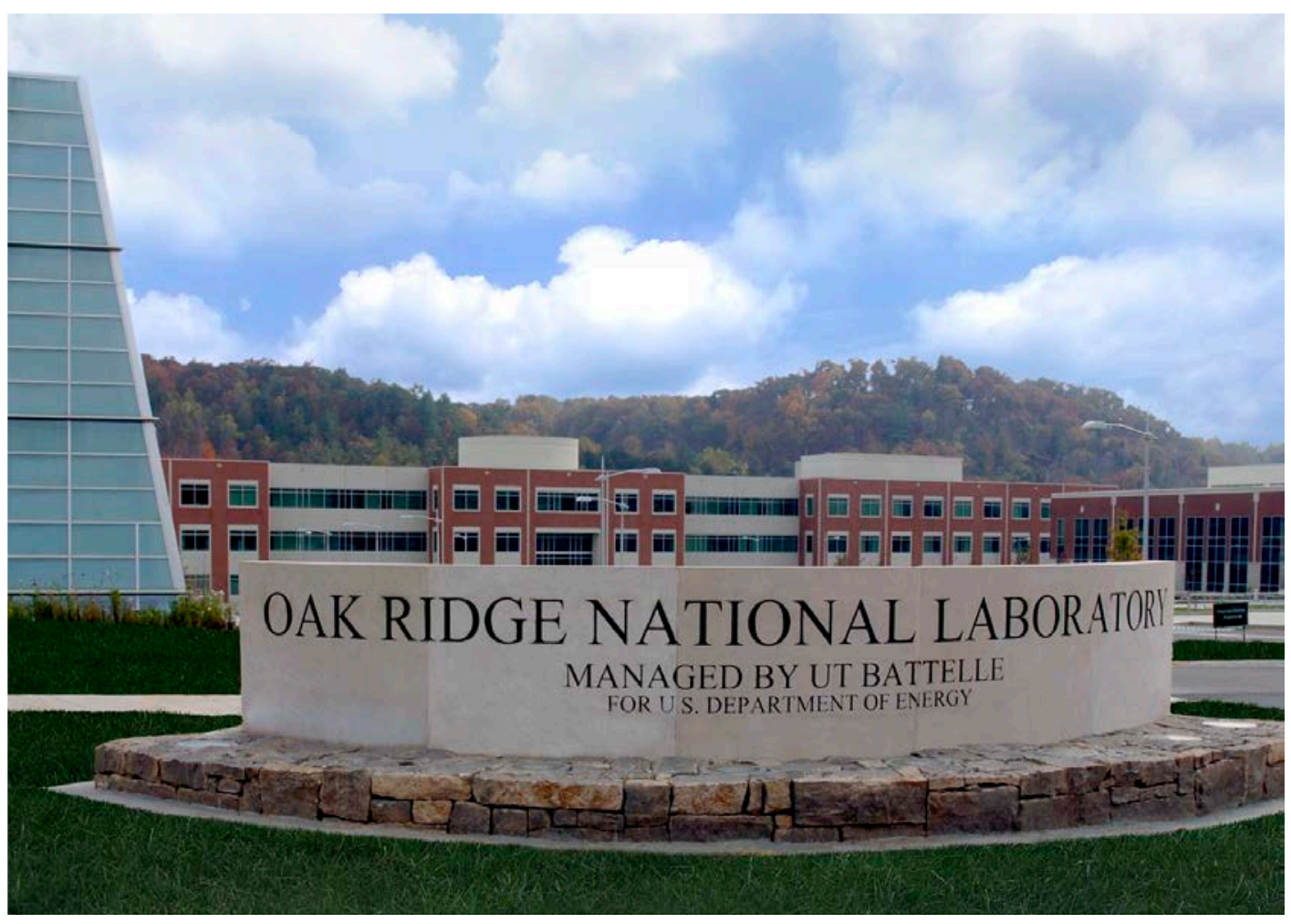

Manfred Kehrer

Simon Pallin

Approved for Public Release . Distribution is Unlimited.

January 17, 2017 


\section{DOCUMENT AVAILABILITY}

Reports produced after January 1, 1996, are generally available free via US Department of Energy (DOE) SciTech Connect.

Website http://www.osti.gov/scitech/

Reports produced before January 1, 1996, may be purchased by members of the public from the following source:

National Technical Information Service

5285 Port Royal Road

Springfield, VA 22161

Telephone 703-605-6000 (1-800-553-6847)

TDD 703-487-4639

Fax 703-605-6900

E-mail info@ntis.gov

Website http://www.ntis.gov/help/ordermethods.aspx

Reports are available to DOE employees, DOE contractors, Energy Technology Data Exchange representatives, and International Nuclear Information System representatives from the following source:

Office of Scientific and Technical Information

PO Box 62

Oak Ridge, TN 37831

Telephone 865-576-8401

Fax 865-576-5728

E-mail reports@osti.gov

Website http://www.osti.gov/contact.html

This report was prepared as an account of work sponsored by an agency of the United States Government. Neither the United States Government nor any agency thereof, nor any of their employees, makes any warranty, express or implied, or assumes any legal liability or responsibility for the accuracy, completeness, or usefulness of any information, apparatus, product, or process disclosed, or represents that its use would not infringe privately owned rights. Reference herein to any specific commercial product, process, or service by trade name, trademark, manufacturer, or otherwise, does not necessarily constitute or imply its endorsement, recommendation, or favoring by the United States Government or any agency thereof. The views and opinions of authors expressed herein do not necessarily state or reflect those of the United States Government or any agency thereof. 
ORNL/TM-2017/026

CRADA/NFE-11-03682

\title{
Energy and Transportation Science Division
}

Hygrothermal Material Properties for Soils in Building Science

Manfred Kehrer

Oak Ridge National Laboratory

Simon Pallin

Chalmers University of Technology, Götenborg, Sweden

\author{
Date Published: \\ January, 2017 \\ Prepared by \\ OAK RIDGE NATIONAL LABORATORY \\ Oak Ridge, Tennessee 37831-6283 \\ managed by \\ UT-BATTELLE, LLC \\ for the \\ US DEPARTMENT OF ENERGY \\ under contract DE-AC05-00OR22725
}

Approved for Public Release 


\title{
HYGROTHERMAL MATERIAL PROPERTIES FOR SOILS IN BUILDING SCIENCE
}

\begin{abstract}
Hygrothermal performance of soils coupled to buildings is complicated because of the dearth of information on soil properties. However they are important when numerical simulation of coupled heat and moisture transport for below-grade building components are performed as their temperature and moisture content has an influence on the durability of the below-grade building component. Soils can be classified by soil texture. According to the Unified Soil Classification System (USCA), 12 different soils can be defined on the basis of three soil components: clay, sand, and silt.

This study shows how existing material properties for typical American soils can be transferred and used for the calculation of the coupled heat and moisture transport of building components in contact with soil. Furthermore a thermal validation with field measurements under known boundary conditions is part of this study, too. Field measurements for soil temperature and moisture content for two specified soils are carried out right now under known boundary conditions. As these field measurements are not finished yet, the full hygrothermal validation is still missing
\end{abstract}




\section{INTRODUCTION}

Hygrothermal performance of soils coupled to buildings is complicated because of the dearth of information on soil properties. A computational approach for heat transfer through the ground has been well defined (EN-ISO-13370 2007), and simplified methods have been developed (Staszczuk et al. 2010). However, these approaches generally ignore the transfer of soil moisture, which is not negligible (Janssen et al. 2004).

The material properties of soils must be reliable for the performance of realistic hygrothermal calculations of soils coupled to buildings, but such material properties are not well defined in present hygrothermal calculation tools. Typical types of building construction that are greatly influenced by soils are basements, crawl spaces, and slabs on grade. Reliable hygrothermal performance indicators for these constructions are sorely needed; requests for this ranked within the top ten Building America Enclosure Research Ideas at the Enclosures STC—Residential Energy Efficiency Stakeholder Meeting held February 29, 2012, in Austin, Texas. The soil science literature contains an extensive amount of measurements on soil properties, but this information must be gathered as well as adapted for application to hygrothermal simulations in building science. Soil properties are important when analyzing and designing both new buildings and retrofits for which the outer boundary of the building enclosure will consist of soil materials. For basement retrofits aimed at energy efficiency, interior solutions to decrease the energy demand must be designed in consideration to existing soil properties. For exterior retrofits, the soil material can be replaced, if needed, with a more suitable filling material, though this approach applies only to basement walls. The soil material beneath the basement floor obviously cannot be replaced; hence the soil properties of this part of a building enclosure still must be taken into consideration.

The intention of this first part is to gather, comprehend, and adapt soil properties from soil science. The obtained information must be applicable to related tasks in building science and validated with hygrothermal calculation tools, where basic changes in the software code may be required in the future. Different types of basement construction will be created with a hygrothermal calculation tool, WUFI. Simulation results from WUFI are to be compared with existing thermal only measurements and will be accomplished with ongoing hygrothermal measurements.

The final outcome of the study will be the evaluation of several soil types in several climate zones for a number of basement assembly types. The study will define the type of soil, together with the type of building construction, considered most and least reliable with respect to energy 
consumption and moisture safety. Further, the study will determine (1) the influences that different soils have on total energy loss through the ground and (2) whether the performance of different soils can be measured solely by a comparison of soil properties

\section{HYGROTHERMAL SOIL PARAMETERS}

Soils can be classified by soil texture. According to the Unified Soil Classification System (USCA), 12 different soils can be defined on the basis of three soil components: clay, sand, and silt (Noorallah 1999). The 12 soil textures in the USCA are presented in the soil texture triangle shown in Figure 1. This study will define the material properties of these 12 soil types. The soil properties of interest for hygrothermal calculations are:

1. Dry bulk and particle density

2. Porosity

3. Thermal conductivity

4. Specific heat capacity

5. Liquid water transfer

These soil properties will be defined in this study for the 12 soil textures presented in Figure 1. These properties will be collected from multiple studies, measurements, and standards; and empirical formulas will be created and used to estimate their variations as a function of different parameters. The influence of gravity on water movement in soil is typically neglected because the water pressure head is usually much higher than the gravitational pressure (Gopalakrishnan and Manik 2007; Prunty 2009).

\section{Moisture Storage Function}

The van Genuchten equations for the estimation of soil hydraulic properties have been widely used since it was first published in 1980 (Neto et al., 2011; van Genuchten, 1980; Zhou \& Yu, 2005), in which the soil water retention curve, WRC, defines the relation between the volumetric water content of the soil as a function of the soil water pressure head, $h$, or suction pressure, $p_{\text {suc }}$. 
The WRC can be obtained using the analytical expression of the effective saturation (also referred as normalized water content), $S_{e}$ :

$S_{e}(h)=\frac{\theta-\theta_{\mathrm{r}}}{\theta_{\mathrm{s}}-\theta_{\mathrm{r}}}=\left[1+(\alpha|h|)^{n}\right]^{-m}$

Hence the volumetric water content can be expressed as:

$\theta(h)=\theta_{\mathrm{r}}+\frac{\theta_{\mathrm{s}}-\theta_{\mathrm{r}}}{\left[1+(\alpha|h|)^{n}\right]^{m}}$

where

$S_{e} \quad=\quad$ effective saturation, -

$\theta=$ volumetric water content, $\mathrm{m}^{3} / \mathrm{m}^{3}$

$\theta_{\mathrm{r}}=$ residual water content, $\mathrm{m}^{3} / \mathrm{m}^{3}$

$\theta_{\mathrm{r}}=$ volumetric water content at saturation, $\mathrm{m}^{3} / \mathrm{m}^{3}$

$h=$ soil water pressure head, $\mathrm{m}$

$\alpha$ and $n$ are fitting parameters $\left(\mathrm{m}^{-1}\right)$ and $(-)$

$m=(1-1 / n),-$

The parameter $n$ is related to the pore size distribution where a larger value corresponds to more uniform pore sizes (Zhou and Yu 2005). The value of $\alpha$ is related to the inverse of the bubbling point, representing the air pressure at the point of air entry into a pore (Schaap et al. 2001) and $m$ is related to the asymmetry of the curve (Zhou and Yu 2005). The soil textures analyzed in this study (the type of soils for which essential properties for hygrothermal simulation will be defined) correspond to the 12 texture classes used by the Natural Resources Conservation Service of the US Department of Agriculture (Noorallah 1999). The soil texture classes are defined in Table 1 where the input parameters of Equation 1 and Equation 2 are based on 560 soil samples obtained from computer software for estimating soil hydraulic characteristics (Schaap 2002). The functions are be either measured directly or estimated indirectly through prediction from more easily measured data based using quasi-empirical models to estimate unsaturated hydraulic properties from surrogate soil data such as soil texture data and bulk density. Models of this type are called 
pedotransfer functions (PTFs) since they translate basic soil data into hydraulic properties and are state of the art in soil science.

The sorption isotherm describes the water content, $w\left(\mathrm{~kg} / \mathrm{m}^{3}\right)$, of a material as a function of the relative humidity, $w(\varphi)$ or $w(\mathrm{RH})$, which is an essential parameter when making hygrothermal calculations with porous materials. Ongoing field measurements will show whether the approach in Equation 1 is valid in the capillary region only or also at relatively dry conditions. The WRC, thus the soil water pressure head, $p_{\text {suc }}$, can be expressed as the relative humidity with the Kelvin equation (Kiessl and Gertis 1980):

$\varphi=e^{\left[\frac{-2 \sigma}{r \cdot \rho_{w} \cdot R_{D} \cdot T}\right]}$

And

$p_{\text {suc }}=\frac{2 \cdot \sigma \cdot \cos \gamma}{r}$

where

$\varphi \quad=$ Relative air humidity $\quad(\%)$

$\sigma \quad=$ Surface tension coefficient $\quad(\mathrm{N} / \mathrm{m})$

$r \quad=$ Radius of capillary tube $\quad(\mathrm{m})$

$\rho_{w} \quad=$ Density of water $\quad\left(\mathrm{kg} / \mathrm{m}^{3}\right)$

$R_{D} \quad=$ Water vapor gas constant $\quad(\mathrm{J} / \mathrm{kg}-\mathrm{K})$

$=461.5$

$T \quad=$ Temperature

$p_{\text {suc }} \quad=$ Suction pressure

(K)

$\gamma \quad=$ Contact angle

The contact angle, $\gamma$, between the water meniscus and the capillary walls can be assumed equal to zero (Hagentoft 2001) due to the hydrophilic properties of the pore wall in stony or wood based materials (Hens 2007), as for soils. Hence the radius of the capillary tube can be expressed as 
$r=\frac{2 \cdot \sigma}{p_{\text {suc }}}$

The relative humidity in Equation 3 can be expressed as function of $p_{\text {suc }}$ :

$\varphi\left(p_{\text {suc }}\right)=e^{\left[\frac{-p_{s u c}}{\rho_{w^{\prime}} R_{D} \cdot T}\right]}$

The soil water pressure head, $h$, can be described as suction pressure, $p_{\text {suc }}$ :

$h \cdot g \cdot \rho_{w}=p_{\text {suc }}$

Combining Equation 6 and Equation 7 results in:

$h(\varphi)=\frac{-\ln \varphi}{g \cdot \rho_{w}^{2} \cdot R_{D} \cdot T}$

Further, the volumetric water content in Equation 2 are given as a function of $\varphi$

$\theta(\varphi)=\theta_{\mathrm{r}}+\frac{\theta_{\mathrm{s}}-\theta_{\mathrm{r}}}{\left[1+\left(\alpha\left(\frac{-\ln \varphi}{g \cdot \rho_{w}^{2} \cdot R_{D} \cdot T}\right)\right)^{n}\right]^{m}}$

The relation between the water content, $w$, and the volumetric water content, $\theta$, is:

$w=\rho_{w} \cdot \theta$

Finally $w$ can be expressed as a function of $\varphi$ using the van Genuchten equation: 
$w(\varphi)=\rho_{w}\left[\theta_{\mathrm{r}}+\frac{\theta_{\mathrm{s}}-\theta_{\mathrm{r}}}{\left[1+\left(\alpha\left(\frac{-\ln \varphi}{g \cdot \rho_{w}{ }^{2} \cdot R_{D} \cdot T}\right)\right)^{n}\right]^{m}}\right]$

Obviously $\varphi$ in [6] cannot be described solely as a function of the $p_{\text {suc }}$. when considering the moisture storage. Temperature also has an influence on the suction pressure, though proven almost insignificant in the temperature range between $0^{\circ} \mathrm{C}$ and $20^{\circ} \mathrm{C}$ (Figure 2). Therefore, in this study, the temperature is assumed to be $10^{\circ} \mathrm{C}$. The resulting moisture storage functions of the 12 soil textures, based on Equation 11, are presented in Appendix A.

Hysteresis is defined as the difference in moisture storage capacity of a material depending on the state from which the material is moving from. A material that is in a drying process has a higher moisture storage capacity at a given $\varphi$ than a material that is in a wetting process (Hagentoft 2001). The effect of hysteresis on hydraulic soil properties has been investigated (Šimunek et al. 1999) but will not be taken into account for the moisture storage capacity due to software limitations, though considered in the liquid diffusivity, defined later in this paper.

\section{Liquid Water Transfer}

The liquid diffusivity, $D$, can be defined for one-dimensional water flux as a function of $K(\theta)$ and WRC (Gopalakrishnan and Manik 2007; Hills et al. 1989; Prunty 2009):

$D(\theta)=K(\theta) \frac{\partial h}{\partial \theta}$

in which $K$ is hydraulic conductivity as a function of volumetric water content. Further, liquid diffusivity can be expressed as a function of the effective saturation, $\mathrm{Se}$, for unsaturated soils (van Genuchten 1980):

$D\left(S_{e}\right)=\frac{(1-m) K_{S}}{\alpha m\left(\theta_{S}-\theta_{r}\right)} S_{e^{\left(\frac{1}{2}-\frac{1}{m}\right)}}\left[\left(1-S_{\left.e^{\frac{1}{m}}\right)^{-m}}+\left(1-S_{\left.\left.e^{\frac{1}{m}}\right)^{m}-2\right]}\right.\right.\right.$ 
where

$D \quad=$ Liquid diffusivity ( $\mathrm{cm}^{2} /$ day)

$K_{s} \quad=$ Saturated hydraulic conductivity $\quad(\mathrm{cm} /$ day)

All other variables are specified in [2].

In addition, the value of liquid diffusivity varies according to whether the soil is being dried or wetted (i.e., an effect of hysteresis). The liquid diffusivity for a soil that is being dried is referred to as drying or drainage diffusivity, whereas a soil being wetted is referred to as wetting or absorption diffusivity. In this study, the terms drying diffusivity, $D_{d r y}$, and wetting diffusivity, Dwet, are applied. Equation 13 represents the drying liquid diffusivity (Mabirizi 2000); hence:

$D\left(S_{e}\right)=D_{d r y}\left(S_{e}\right)$

Consequently, the wetting diffusivity also needs to be established. There exist very few measurements of both drying and wetting diffusivities where the latter can be determined either by Mitchell's test method (Mabirizi and Bulut 2009) or by the relation between the drying and wetting diffusivities in which either of the unknown diffusivities can be estimated. In this study, a relation factor $\beta$ is applied:

$D_{\text {wet }}=\beta \cdot D_{d r y}$

The effects of the disparity between the wetting and drying soil conditions and of the moisture storage function in Equation 11 have been investigated, using the input parameters of van Genuchten (Šim nek et al. 1999). According to the authors, the hysteresis can be taken into account for WRC of unsaturated soils by making the following assumption of the fitting parameter $\alpha$ :

$\alpha_{w e t}=2 \cdot \alpha_{d r y}$

This assumption is proven to work well for the moisture storage function in Equation 2 (Šimnek et al. 1999). According to a study of 40 different samples comprising six different soil types, the relation factor, $\beta$, may vary between 0.6 and 3.9 (Mabirizi and Bulut 2009), where the overall 
average from the measurements is 1.75 , but only parts of the 12 soil types were investigated in that study.

In this study, $D_{d r y}$ is determined with Equation 13 together with the input parameters defined for the 12 soil textures in Table 1. $D_{\text {wet }}$ is determined with the relation factor of 1.75 in Equation 15. $D_{d r y}$ values for the defined soil texture classes are presented in Appendix B together with $D_{\text {wet }}$ for clay and silt. The necessity of distinguishing the liquid diffusivity into $D_{d r y}$ and $D_{\text {wet }}$ might be questionable due the small disparity of their distributions. Still, the two different diffusivities remain in this study.

The liquid diffusivities are presented together with the moisture content, $w$, which can be expressed as a function of effective saturation:

$w\left(S_{e}\right)=\left(S_{e}\left(\theta_{\mathrm{s}}-\theta_{\mathrm{r}}\right)+\theta_{\mathrm{r}}\right) \rho_{w}$

from combining [1] and [10].

\section{Vapor Diffusion Resistance Factor}

The water vapor diffusion resistance factor, $\mu$, that is, the rate of vapor diffusion through a material in comparison with stagnant air, is typically assumed to be 50 for soils (EN-12524 2000), which corresponds to a permeability of about 2.6 perm-in.

\section{Dry Bulk Density, Particle Density and Porosity}

The bulk density of soil is the combined weight of the soil solids, water, and air divided by the bulk volume $\left(\mathrm{kg} / \mathrm{m}^{3}\right)$. The dry bulk density, $\rho_{b}$, which is an important material property, is the bulk density for a completely dry soil. The bulk density typically increases with soil depth on account of reduced organic materials and natural compaction (USDA 2008). Compaction is the phenomenon by which soils are compressed, which usually decreases the porosity (Richard et al. 2001) and thus the ability for water and vapor absorption. Other research has shown that the bulk 
density varies mainly down to $0.3 \mathrm{~m}$ (Kim et al.2010) where a 7\% increase in bulk density can be expected from 0 to $1 \mathrm{~m}$ (Ray et al. 2004). In this study, the effect of compaction will not be taken into account when estimating soil material properties.

In addition, the bulk density depends on the soil type (Keller and Håkansson 2010). Table 2 presents $\rho_{b}$ for the 12 specified soil textures, based on average values from 560 soil samples (Schaap 2002).

The particle density, $\rho_{s}$, in soils is defined as the mass of the solids divided by the volume of the solids. Consequently, without considering the volume of the pores or the mass of liquid and gas inside the pores, the particle density can be used to determine the porosity, $n$, in relation with the bulk density:

$n=\left(1-\frac{\rho_{b}}{\rho_{s}}\right) \geq \theta_{\mathrm{s}}$

Naturally, the volumetric water content at saturation, $\rho_{s}$, cannot exceed the porosity if the swelling phenomenon is neglected. The particle density of soils and earth materials is typically assumed to be $2650 \mathrm{~kg} / \mathrm{m}^{3}$ (Blanco-Canqui et al. 2006; Eshel et al. 2004) though variation exists between 2400 and $2900 \mathrm{~kg} / \mathrm{m}^{3}$ depending on the composition of minerals and organic components (Rühlmann et al. 2006). An existing study presents the particle densities from 176 experimental sites (Keller and Håkansson 2010) which include nine of the 12 defined soil textures. In this study these variations are applied. The particle density of the other three soil textures, which is not included, is assumed to equal $2650 \mathrm{~kg} / \mathrm{m}^{3}$. The particle densities and porosities for the 12 soil textures are presented in Table 2.

\section{Thermal Conductivity and Heat Capacity}

The thermal conductivity, $k$, of soils increases with the moisture content (Abu-Hamdeh 2003). Other factors that influence the conductivity, though slightly, are mineral composition, temperature, soil texture, and time (Becker and Fricke 1997). An empirical solution of $k$ has been 
defined on the basis of the available data collected from the literature as a function of effective saturation, Se, of three different soil textures: sand, silt, and clay (Becker and Fricke 1997):

$S_{e}(k)=\lambda_{1}\left[\sinh \left(\lambda_{2} \cdot k+\lambda_{3}\right)-\sinh \left(\lambda_{4}\right)\right]$

hence $k$ can be defined as:

$k\left(S_{e}\right)=\frac{-\left(\lambda_{3}-\operatorname{arsins}\left(\sinh \left(\lambda_{4}\right)+\frac{S_{e}}{\lambda_{1}}\right)\right)}{\lambda_{2}}$

where

$S_{e} \quad=$ Effective saturation

$k=$ Soil thermal conductivity

$\lambda_{1-4} \quad=$ Coefficients varying with soil type

$(-)$

The results of calculating the soil thermal conductivity by Equation 20 for clay, sand, and silt are presented in Appendix C, though as a function of water content, $w$. The water content is expressed as a function of effective saturation in Equation 17; hence $k(w)$ becomes:

$k(w)=\frac{-\left(\lambda_{3}-\operatorname{arsins}\left(\sinh \left(\lambda_{4}\right)+\frac{\left(w \cdot \rho_{w}{ }^{-1}-\theta_{\mathrm{r}}\right)}{\left(\theta_{\mathrm{s}}-\theta_{\mathrm{r}}\right) \lambda_{1}}\right)\right)}{\lambda_{2}}$

The soil thermal conductivities for clay, sand, and silt, both frozen and unfrozen, are presented in Appendix C in relation to soil water content. Of the 12 soil textures defined by the USCA, sand, silt, and clay are the three major ones, with the other nine textures defined from them. No coefficients are presented for these nine textures (Becker and Fricke 1997) since, in this study, an interpolation has been made based on the distributions of the thermal conductivity of clay, sand, and silt. The interpolation is also based on the assumption that these three major textures are not pure clay, sand, and silt; instead, they are assumed to have their average composition given by Figure 1. The reason behind this approach is that the coefficients for the thermal conductivity presented in Table 3 are based on multiple samples within the range of clay, sand, or silt. Thus the coefficients of clay, sand, and silt represent average values. The assumed compositions of the three provided soil textures are presented in Table 4 . The soil compositions are the basis for 
obtaining the thermal conductivities for intermediate soil textures with a system of linear equations. This method, together with results, is presented in Appendix D.

The resulting soil thermal conductivities for sand, loam, silt, and clay are presented in Figure 3. The distribution of loam rely on their defined portion of clay, sand, and silt, which then are implemented into the result of a system of linear equations described in Appendix C.

The specific heat capacity of dry soils, cdry, can vary from 710 to $1550 \mathrm{~J} / \mathrm{kgK}$ (Olchev et al. 2009), though most commonly cdry is assumed to be about $850 \mathrm{~J} / \mathrm{kgK}$ (Acs et al.1990; Kung and Steenhuis 1986) where the actual volumetric heat capacity of the soil, $c$, increases linearly with the soil moisture content:

$c=\rho_{b} \cdot c_{d r y}+w \cdot c_{w}$

where $\rho_{b}$ is the dry bulk density $\left(\mathrm{kg} / \mathrm{m}^{3}\right), w$ is the water content and $c_{w}$ is the specific heat capacity of water (J/kg-K).

\section{VALIDATION WITHTHERMAL SOIL MEASUREMENT}

Since 1987 the temperatures at different depths of a local soil have been measured at Fraunhofer Institute for Building Physics in Holzkirchen, Germany. Three different temperatures are measured hourly: at the surface and at the depths of 0.5 and $1.0 \mathrm{~m}$. Simultaneously, at the same location, comprehensive weather data have been measured, which enables the thermal behavior of the soil to be validated by a computer simulation. The typical soil in the Holzkirchen area is loamy sand (LFU Bayern 2012), the properties of which are applied in the simulation model discussed previously.

In this study, the period from 2005 to 2009 has been simulated in WUFI 1D (Künzel 1995) for the comparison and thermal validation of the soil properties. The model has been designed to represent the semi-infinite conditions of one dimensional heat transfer through the ground according to Figure 4. 
Typically, the precipitation in a simulation model functions as a boundary condition in which the moisture load initially affects only the grid element closest to the border, e1. If this element is saturated, it will not have further moisture storage capacity; hence, the surplus of moisture is neglected. This assumption is acceptable for a surface with drainage (e.g., a vertical wall) though not applicable in soils in which most of the precipitation will be absorbed eventually. Instead, in this model, the precipitation is distributed directly into the first four elements, e1 to e4, as an impregnated source (see Figure 4). This approach decreases the amount of precipitation neglected during the simulation run and serves as the best practice manageable with the current WUFI model.

The temperature variations of the ground vary with the surface temperature, with the amplitude of the average temperature decreasing with ground depth. At the depth of $10 \mathrm{~m}$, the annual temperature variation of a typical soil is about $4 \%$ of the temperature variation at the surface (Hagentoft 2001). At the depth of $20 \mathrm{~m}$, the corresponding variation is $0.2 \%$, which is the depth used in the simulation model of this study. The average ground temperature at Holzkirchen is estimated to $9.5^{\circ} \mathrm{C}$ (Heidreich 2006) which is the assumed constant temperature at the ground boundary (i.e., at the depth of $20 \mathrm{~m}$ ). This approach simplifies the semi-infinite temperature variations of the ground for a model defined by boundaries.

The moisture transfer of the ground behaves accordingly. In this study, the starting moisture content of the soil is based on 10 years of pre-simulation where the moisture content of the lower boundary remains constant. This assumption does not enable moisture to pass the lower boundary; hence the moisture content of the simulation model, at different depths, varies solely on the basis of the variation of the moisture content at the upper surface of the ground. Future enhancements to the WUFI software will attend to this deficiency.

The results of the comparison between simulated and measured ground temperature in soil at Holzkirchen are presented in Figure 5. The slightly lower simulated ground temperature between July and October could be a result of a too high surface heat transfer coefficient. In the simulation model, the wind-driven heat transfer coefficient is assumed to represent the clean horizontal surface of a flat roof, though in reality there are other factors that should be taken into 
account. First, the surface of the ground is not clean and smooth. The texture of the grass will affect the surface wind velocity, thus the convection induced heat transfer. Further, the measurement of the ground temperature is taken in the vicinity of other objects, such as buildings, which naturally also will have an effect. A brief analysis of the effects of these factors on the heat transfer coefficient was performed, revealing a better fit between the measured and the simulated temperature variations.

Additionally, neither snow coverage nor its effect on the surface thermal resistance and long- and short-wave radiation is taken into account in the simulation.

\section{DISCUSSION AND CONCLUSIONS}

The soil properties of interest in building science have been defined for 12 different soil textures. These properties can serve as input parameters when performing hygrothermal calculations of building constructions coupled to soil materials. The reliability of the soil parameters will be further evaluated with measurements in ongoing hygrothermal measurements.

The moisture storage capacity, $w$, ranges from $49 \mathrm{~kg} / \mathrm{m}^{3}$ in loamy sand and $138 \mathrm{~kg} / \mathrm{m}^{3}$ in sandy clay to $375 \mathrm{~kg} / \mathrm{m}^{3}$ in sand and $489 \mathrm{~kg} / \mathrm{m}^{3}$ in silt. In sand, the moisture storage capacity increases insignificantly for relative humidity below 99.8\%, which makes sand nonhygroscopic. Loamy sand shows similar behavior as sand with regard to the moisture storage function. Of the 12 defined soil textures, the moisture storage capacity increases most rapidly for clay.

The liquid diffusivity must be distinguished into two types, wetting and drying diffusivities, of which the latter is usually a little smaller. The drying diffusivity is commonly measured and expressed in existing literature; hence a relation factor for the wetting diffusivity has been established and applied in this study.

The thermal conductivities for clay, sand, and silt have been defined in existing studies. The other nine defined soil textures have been estimated by combining the thermal conductivities of these three soil components. 
The comparison of measured and simulated ground temperature at the depth of $1 \mathrm{~m}$ shows rather good agreement, though improvements to the simulation model are required. Currently, WUFI does not allow full absorption of precipitation at the surface border if the outer element is moisture saturated. Further, the moisture transfer at the lower boundary (i.e., the border representing the infinite ground) should be improved to better simulate the existing moisture transfer mechanisms at this border. Consequently, changes in the existing software code WUFI must be implemented to consider the effects discussed regarding liquid uptake of precipitation and liquid flow through and out of the simulated system.

Field measurements for soil temperature and moisture content for two specified soils are carried out right now under know boundary conditions. These data will allow a full comparison between measurement and simulation. This will tell us whether the simplification in the material properties and in the calculation model is acceptable.

The heat transfer coefficient at the soil surface varies with a number of factors that are not yet included in the simulation model. Once these improvements are implemented, the simulations results are more likely to better fit the measurements.

An example of a factor not yet included is the effect on the wind-driven heat transfer coefficient resulting from the texture of the grass and the influence of surrounding objects. In addition, snow coverage of the ground, along with its effect on the surface thermal resistance and long- and short-wave radiation, has not been taken into account yet.

\section{ACKNOWLEDGEMENTS}

This study was sponsored by the U.S. Department of Energy Building Technologies Program under contract DEAC05- 00OR22725.

\section{REFERENCES}

Abu-Hamdeh, N.H. (2003). Thermal Properties of Soils as affected by Density and Water Content. Biosystems Engineering, 86(1), 97-102. doi: 10.1016/s1537- 5110(03)00112-0 
Acs, F., Mihailovic, D., and Rajkovic, B. (1990).A coupled soil moisture and surface temperature prediction model. Journal of Applied Meteorology, 30(6).

Becker, R.B., and Fricke, B.A. (1997). Effects of Saturation and Dry Density on Soil Thermal Conductivity. Department of Mechanical and Aerospace Engineering, University of MissouriKansas City, MO, USA.

Blanco-Canqui, H., Lal, R., Post, W.M., Izaurralde, R.C., and Shipitalo, M.J. (2006). Organic carbon influences on soil particle density and rheological properties. Soil Science Society of America Journal, 70(4), 1407-1414.

Duble, R. (2011). Turfgrass Rootzones - Introduction - Soil Texture Triangle Retrieved 201206-11

EN-12524. (2000). Wärme- und feuchteschutztechnische Eigenschaften Tabellierte Bemessungswerte Baustoffe und -produkte: Deutsche Norm.

EN-ISO-13370:. (2007). EN ISO 13370:2007 Thermal performance of buildings - Heat transfer via the ground - Calculation Methods TC 163 Thermal Performance and Energy Use in the Built Environment - TC 163/SC 2 - Calculation methods: European standard.

Eshel, G., Levy, G.J., Mingelgrin, U., and Singer, M.J. (2004). Critical evaluation of the use of laser diffraction for particle- size distribution analysis. Soil Science Society of America Journal, 68(3), 736-743.

Gopalakrishnan, K., and Manik, A. (2007). A Mathematical Model for Predicting Isothermal Soil Moisture Profiles Using Finite Difference Method. International Journal of Computational and Mathematical Sciences (1:2 2007).

Hagentoft, C.E. (2001). Introduction to Building Physics. Lund, Sweden: Studentlitteratur.

Heidreich, U. (2006). Nutzung oberflächennaher Geothermie zum Heizen und Kühlen eines Bürogebäudes. Paper presented at the Symposium Energetische Sanierung von SchulundVerwaltungsgebäuden, FH Münster.

Hens, H. (2007). Building Physics Heat, Air and Moisture - Fundamentals and Engineering Methods with Examples and Exercises. Germany: Ernst and Sohn Verlag fur Architektur und technischeWissenschaften GmbH und Co. KG, Berlin.

Hills, R.G., Hudson, D.B., Porro, I., andWierenga, P.J. (1989). Modeling One-Dimensional Infiltration into Very Dry Soils. 2. Estimation of the Soil-water Parameters and Model Predictions. Water Resources Research, 25(6), 1271-1282. doi: 10.1029/WR025i006p01271 
Janssen, H., Carmeliet, J., and Hens, H. (2004). The influence of soil moisture transfer on building heat loss via the ground. Building and Environment, 39(7), 825-836. doi:

10.1016/j.buildenv.2004.01.004

Keller, T., and Håkansson, I. (2010). Estimation of reference bulk density from soil particle size distribution and soil organic matter content. Geoderma, 154(3-4), 398-406. doi:

10.1016/j.geoderma.2009.11.013

Kiessl, K., and Gertis, K. (1980). Feuchtetransport in Baustoffen: Eine Literaturauswertung zur rechnerischen Erfassung hygrischer Transportphänomene: Univerität Essen Gesamthochschule.

Kim, H., Anderson, S.H., Motavalli, P.P., and Gantzer, C.J. (2010). Compaction effects on soil macropore geometry and related parameters for an arable field. Geoderma, 160(2), 244-251. doi: 10.1016/j.geoderma.2010.09.030

Kung, S.K.J., and Steenhuis, T.S. (1986). Heat and moisture transfer in a partly frozen nonheaving soil. Soil Science Society of America Journal, 50(5), 1114-1122.

Künzel, H.M. (1995). Simultaneous Heat and Moisture Transport in Building Components. One- and two dimensional calculation using simple parameters. Dissertation, University Stuttgart, IRB Verlag. Retrieved from www.WUFI.com

LFU_Bayern (2012). [Personal communication—Bayerisches Landesamt fuer Umweltschutz; Bodenkundliche Aufnahme].

Mabirizi, D. (2000). Wetting and Drying Unsaturated Soil Diffusivity Measurements in Laboratory. Master, Oklahoma State University.

Mabirizi, D., and Bulut, R. (2009). Unsaturated Soil Moisture Drying and Wetting Diffusion Coefficient Measurements in the Laboratory: School of Civil and Environmental Engineering, Oklahoma State University/Oklahoma Transportation Center.

Neto, D.D., van Lier, Q.D., van Genuchten, M.T., Reichardt, K., Metselaar, K., and Nielsen, D.R. (2011). Alternative Analytical Expressions for the General van Genuchten- Mualem and van Genuchten-Burdine Hydraulic Conductivity Models. [Article]. Vadose Zone Journal, 10(2), 618- 623. doi: 10.2136/vzj2009.0191

Noorallah, G.J. (1999).Volume 01: Introduction to Soil Science and Soil Resources: Salman Productions Inc.

Olchev, A., Radler, K., Sogachev, A., Panferov, O., and Gravenhorst, G. (2009). Application of a three-dimensional model for assessing effects of small clear-cuttings on radiation and soil temperature. Ecological Modelling, 220(21), 3046-3056. doi: 10.1016/j.ecolmodel.2009.02.004

Prunty, L. (2009). Soil Water Thermal Liquid Diffusivity. Soil Science Society of America Journal, 73(3), 704-706. doi: 10.2136/sssaj2008.0097 
Ray, C., Vogel, T., and Dusek, J. (2004). Modeling depth-variant and domain-specific sorption and biodegradation in dual-permeability media. Journal of Contaminant Hydrology, 70(1-2), 63-87. doi: 10.1016/j.jconhyd.2003.08.009

Richard, G., Cousin, I., Sillon, J.F., Bruand, A., and Guérif, J. (2001). Effect of compaction on the porosity of a silty soil: influence on unsaturated hydraulic properties. Effet du compactage sur la porosité d'un sol limoneux: consequences sur les propriétés hydrauliques en non saturé. European Journal of Soil Science, 52(1), 49-58. doi: 10.1046/j.1365-2389.2001.00357.x

Rühlmann, J., Körschens, M., and Graefe, J. (2006). A new approach to calculate the particle density of soils considering properties of the soil organic matter and the mineral matrix. Geoderma, 130(3-4), 272-283. doi: 10.1016/j.geoderma. 2005.01.024

Schaap, M.G. (2002). Rosetta: A computer program for estimating soil hydraulic parameters with hierarchical pedotransfer functions (Version 1.2). http://cals.arizona.edu/ research/rosetta/rosetta.html.

Schaap, M.G., Leij, F.J., and van Genuchten, M.T. (2001). Rosetta: a computer program for estimating soil hydraulic parameters with hierarchical pedotransfer functions. Journal of Hydrology, 251(3-4), 163-176. doi: 10.1016/s0022- 1694(01)00466-8

Šim nek, J., Kodešová, R., Gribb, M.M., and van Genuchten, M.T. (1999). Estimating hysteresis in the soil water retention function from cone permeameter experiments. Water Resour. Res., 35(5), 1329-1345. doi: 10.1029/ 1998wr900110

Staszczuk, A., Radon, J., and Holm, A. (2010). Evaluation of simplified calculation method of heat exchange between building and ground.

USDA, N.R.C.S. (2008). Soil quality indicators-Bulk density (pp. 2). USDA, Natural Resources Conservation Service.

van Genuchten, M.T. (1980). A Closed-form Equation for Predicting the Hydraulic Conductivity of Unsaturated Soils. Soil Science Society of America Journal, 44(5), 7.

Zhou, J., and Yu, J. L. (2005). Influences affecting the soil-water characteristic curve. Journal of Zhejiang University, 6(8), 8. 


\section{List of Figure Captions}

Soil texture triangle representing the 12 classes of soil texture used by the Natural

Figure 1 Resources Conservation Service of the US Department of Agriculture (Duble 2011; Noorallah 1999)

Figure 2 Moisture storage function of loam at fixed temperatures of $0^{\circ} \mathrm{C}$ and $20^{\circ} \mathrm{C}$. The moisture content of the soil is defined in the range $96 \%-100 \%$ rh.

Thermal conductivity for sand, loam, silt, and clay as a function of the water content

Figure 3 of the soils. The distribution of loam are based on determining their compositions and on the provided distributions of clay, sand, and silt (see Appendix C).

Simulation model representing one-dimensional and semi-infinite hygrothermal transfer through the ground. The soil material in the simulation model is loamy sand

Figure 4 from which the temperature variation at the depth of $1 \mathrm{~m}$ is compared with measurements. The temperature is assumed constant at a depth of $20 \mathrm{~m}$, and the border moisture is assumed to be adiabatic.

Comparison between measured and simulated ground temperature at the depth of 1

Figure $5 \mathrm{~m}$ in Holzkirchen, Germany. The presented variations in temperature occurred during the year 2008, and the soil texture was loamy sand. 


\section{Table(s) with Caption(s)}

Table 1. Average Hydraulic Parameters Required in Equation 1 to Calculate the Saturation Effect and in Equation 13 to Calculate the Liquid Diffusivity. The values are based on 560 Soil Samples (Schaap 2002).

\begin{tabular}{|l|l|l|l|l|l|l|}
\hline Soil Texture & $\theta_{\boldsymbol{r}}, \mathbf{m}^{\mathbf{3}} / \mathbf{m}^{\mathbf{3}}$ & $\theta_{\boldsymbol{s}}, \mathbf{m}^{\mathbf{3}} / \mathbf{m}^{\mathbf{3}}$ & $\alpha, \mathbf{~ m}^{-1}$ & $\mathbf{n},-$ & $\mathbf{m},-$ & $\boldsymbol{K}_{\boldsymbol{s}}, \mathbf{~ m} / \mathbf{s}$ \\
\hline Clay & 0.10 & 0.46 & $1 \times 10^{-4}$ & 1.25 & 0.20 & $1.7 \times 10^{-6}$ \\
\hline Clay Loam & 0.08 & 0.44 & $2 \times 10^{-4}$ & 1.42 & 0.29 & $9.3 \times 10^{-7}$ \\
\hline Loam & 0.06 & 0.40 & $1 \times 10^{-4}$ & 1.47 & 0.32 & $1.4 \times 10^{-6}$ \\
\hline Loamy Sand & 0.05 & 0.39 & $3 \times 10^{-4}$ & 1.75 & 0.43 & $1.2 \times 10^{-5}$ \\
\hline Sand & 0.05 & 0.38 & $4 \times 10^{-4}$ & 3.18 & 0.69 & $7.4 \times 10^{-5}$ \\
\hline Sandy Clay & 0.12 & 0.39 & $3 \times 10^{-4}$ & 1.21 & 0.17 & $1.3 \times 10^{-6}$ \\
\hline Sandy Clay Loam & 0.06 & 0.38 & $2 \times 10^{-4}$ & 1.33 & 0.25 & $1.5 \times 10^{-6}$ \\
\hline Sandy Loam & 0.04 & 0.39 & $3 \times 10^{-4}$ & 1.45 & 0.31 & $4.4 \times 10^{-6}$ \\
\hline Silt & 0.05 & 0.49 & $1 \times 10^{-4}$ & 1.68 & 0.40 & $5.1 \times 10^{-6}$ \\
\hline Silty Clay & 0.11 & 0.48 & $2 \times 10^{-4}$ & 1.32 & 0.24 & $1.2 \times 10^{-6}$ \\
\hline Silty Clay Loam & 0.09 & 0.48 & $1 \times 10^{-4}$ & 1.52 & 0.34 & $1.3 \times 10^{-6}$ \\
\hline Silt Loam & 0.07 & 0.44 & $1 \times 10^{-4}$ & 1.66 & 0.40 & $2.1 \times 10^{-6}$ \\
\hline
\end{tabular}

Table 2. Average Hydraulic Parameters Required in Equation 1 to Calculate the Saturation Effect and in Equation 13 to Calculate the Liquid Diffusivity. The values are based on 560 Soil Samples (Schaap 2002).

\begin{tabular}{|l|l|l|l|}
\hline Soil Texture & Dry Bulk Density, $\boldsymbol{\rho}_{\mathbf{b}}, \mathbf{k g} / \mathbf{m}^{\mathbf{3}}$ & Particle Density, $\boldsymbol{\rho}_{\mathbf{b}}, \mathbf{k g} / \mathbf{m}^{\mathbf{3}}$ & Porosity, $\mathbf{n , ~ \%}$ \\
\hline Clay & 1270 & 2620 & 52 \\
\hline Clay Loam & 1360 & 2600 & 48 \\
\hline Loam & 1290 & 2600 & 50 \\
\hline Loamy Sand & 1510 & 2640 & 43 \\
\hline Sand & 1580 & 2650 & 40 \\
\hline Sandy Clay & 1400 & 2650 & 47 \\
\hline Sandy Clay Loam & 1520 & 2620 & 42 \\
\hline Sandy Loam & 1550 & 2580 & 40 \\
\hline Silt & 1390 & 2650 & $48(49)^{\mathrm{a}}$ \\
\hline Silty Clay & 1400 & 2610 & $47(48)^{\mathrm{a}}$ \\
\hline Silty Clay Loam & 1280 & 2590 & 50 \\
\hline Silt Loam & 1390 & 2600 & 45 \\
\hline
\end{tabular}

Table 3. Coefficients for Clay, Sand, and Silt (Frozen and Unfrozen) required to estimate the Soil Thermal Conductivity by Equation 20 (Becker and Fricke 1997)

\begin{tabular}{|ll|l|l|l|l|}
\hline \multirow{2}{*}{ Soil Type } & $\lambda_{1}$ & $\lambda_{2}$ & $\lambda_{3}$ & $\lambda_{4}$ \\
\hline \multirow{2}{*}{ Clay } & Frozen & 14.5 & 1.7 & -2.5 & -2.0 \\
& Unfrozen & 27.0 & 1.8 & -1.5 & -1.0 \\
\hline \multirow{2}{*}{ Sand } & Frozen & 10.0 & 1.7 & -2.2 & -1.6 \\
& Unfrozen & 6.8 & 2.8 & -2.9 & -1.5 \\
\hline \multirow{2}{*}{ Silt } & Frozen & 19.5 & 1.9 & -1.8 & -1.5 \\
& Unfrozen & 17.0 & 2.8 & -2.6 & -1.6 \\
\hline
\end{tabular}


Table 4. Assumed Texture Compositions of Clay, Sand, and Silt. These Compositions are the Basis for Estimating the Unknown Conductivities for the Nine Soil Textures that Are Not Defined in Table 3.

\begin{tabular}{|l|l|l|l|}
\hline \multirow{2}{*}{ Average composition } & \multicolumn{3}{|c|}{} \\
\cline { 2 - 4 } & Clay & Sand & Silt \\
\hline Portion of Clay & $60 \%$ & $5 \%$ & $8 \%$ \\
\cline { 1 - 1 } Portion of Sand & $20 \%$ & $90 \%$ & $8 \%$ \\
\cline { 1 - 1 } Portion of Silt & $20 \%$ & $5 \%$ & $84 \%$ \\
\hline
\end{tabular}




\section{Figures}

Figure 1

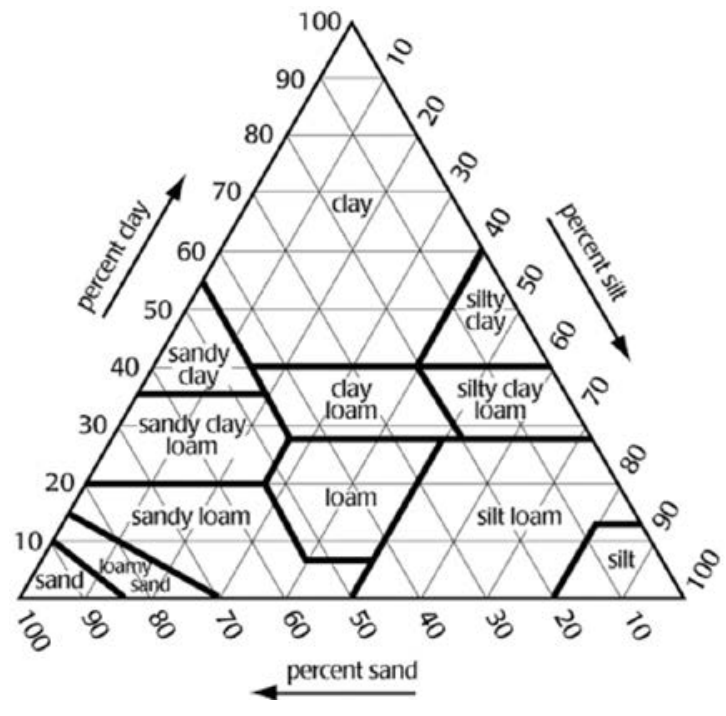

Figure 2

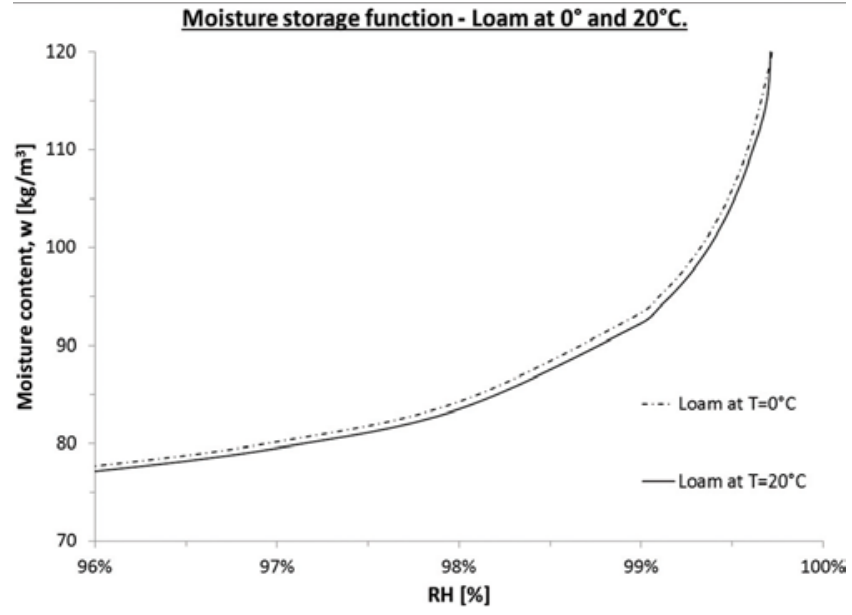

Figure 3

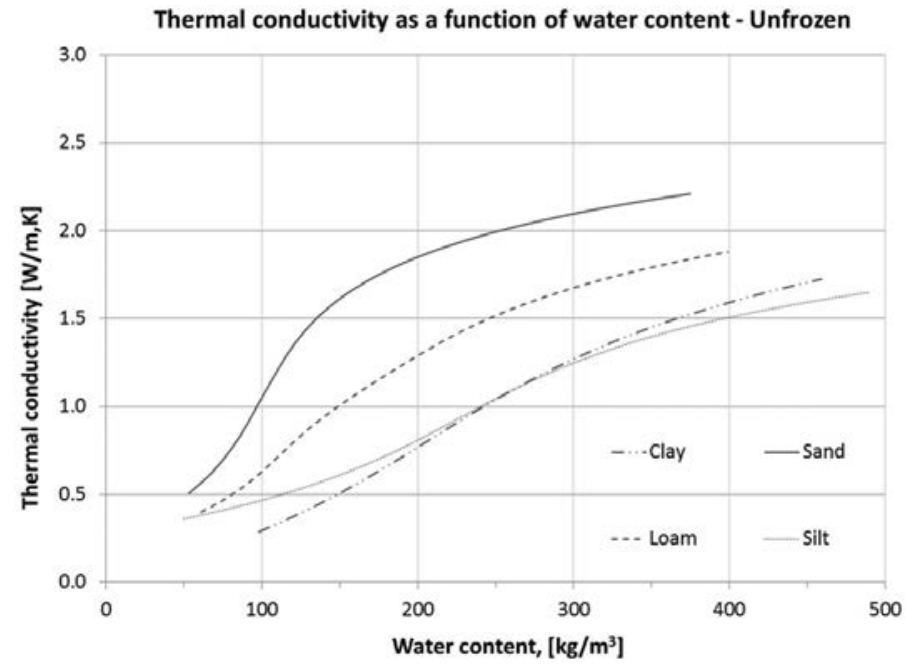




\section{Figure 4}

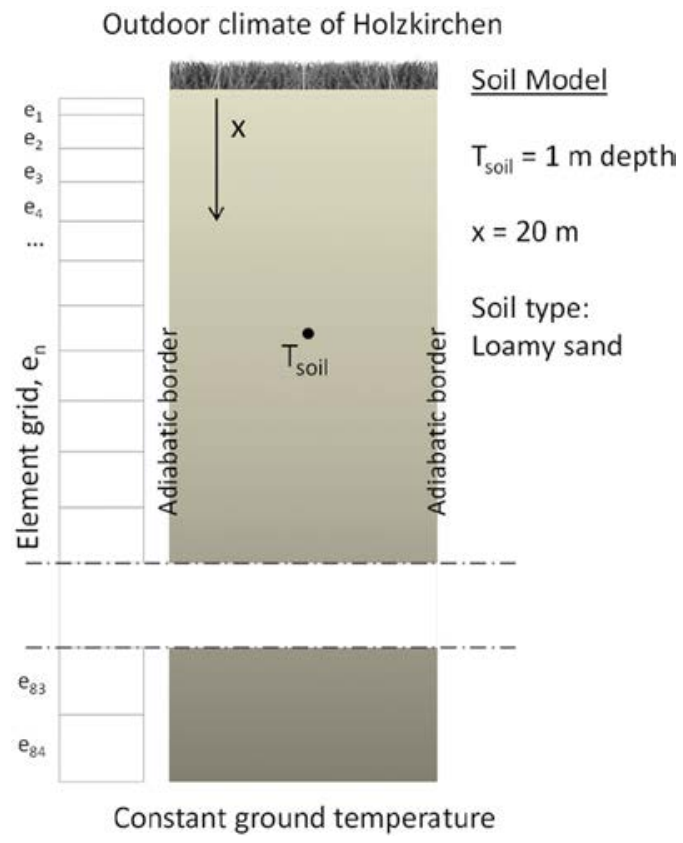

Figure 5




